\title{
EFFECTS OF DIFFERENT WATER REGIMES ON THE ANATOMICAL CHARACTERISTICS OF ROOTS OF GRASSES PROMISING FOR REVEGETATION OF AREAS SURROUNDING HYDROELECTRIC RESERVOIRS
}

\author{
SILVANA DA SILVA ${ }^{2}$ \\ EVARISTO MAURO DE CASTRO ${ }^{3}$ \\ ÂNGELA MARIA SOARES ${ }^{4}$
}

\begin{abstract}
The objective of this study was to evaluate the effect of different water regimes on some aspects of root anatomy of three grasses: Echinochloa pyramidalis (canarana), Setaria anceps (setária) and Paspalum paniculatum (paspalo). The plants were cultivated in a greenhouse and submitted to three water regimes: daily watering; suspension of watering and suspension of watering followed by submersion of the root system. Segments of the middle part of the roots were taken and submitted to classical techniques in botany for slide making and tissue analysis. Anatomical differences were observed among the three grasses
\end{abstract}

submitted to water regimes regarding the number of cell layers in the external cortex and thickening of lignin and suberin. The submerged roots of the three species presented an increasing tendency in the proportion of the area of the cortex destined for the aerenchyma besides thickening of the endodermis and the cells of the medullar parenchyma. The aerenchyma presence in the three water regimes suggested it is a characteristic of these species. The adaptations developed by these species contributed to the understanding of their occurrence in areas that are subject to drought periods and successive floods.

INDEX TERMS: Revegetation, grasses, water deficit, Echinochloa pyramidalis, Setaria anceps, Paspalum paniculatum, flood, aerenchyma, anatomical characteristics, roots.

\section{EFEITOS DE DIFERENTES REGIMES HÍDRICOS SOBRE AS CARACTERÍSTICAS ANATÔMICAS DE RAÍZES DE GRAMINEAS PROMISSORAS PARA REVEGETAČ̃̃ DE ÁREAS MARGINAIS A RESERVATÓRIOS HIDRELETRICOS}

\begin{abstract}
RESUMO - Conduziu-se o presente trabalho objetivavando-se avaliar o efeito de diferentes regimes hídricos sobre alguns aspectos da anatomia da raiz das seguintes gramíneas: Echinochloa pyramidalis (canarana), Setaria anceps (setária) e Paspalum paniculatum (paspalo). As plantas foram cultivadas em casa-de-vegetação e submetidas a três regimes hídricos: regas diárias; suspensão da rega e suspensão da rega seguida de submersão do sistema radicular. Foram retirados segmentos da parte mediana das raízes, os quais foram submetidos a técnicas clássicas em botânica para confecção de lâminas e análise de tecidos. Foram observadas diferenças anatômicas nas três espécies de gramíneas submetidas aos
\end{abstract}

três regimes hídricos com relação ao número de camadas de células do córtex externo e o espessamento de lignina e/ou suberina. As raízes em submersão nas três espécies apresentaram uma tendência de aumento na proporção da área do córtex destinada a aerênquimas, além de um espessamento tanto da endoderme como das células do parênquima medular. Pela presença de aerênquimas nas três espécies sujeitas aos três regimes hídricos, infere-se que esses são constitutivos. As adaptações desenvolvidas por essas espécies contribuíram na compreensão da ocorrência dessas em áreas que passam por períodos de seca e inundações sucessivas.

TERMOS PARA INDEXAÇÃO: Revegetação, gramíneas, deficiência hídrica, inundação, aerênquimas, características anatômicas, Echinochloa pyramidalis, Setaria anceps, Paspalum paniculatum, raízes.

\footnotetext{
1. Parte da dissertação do primeiro autor apresentada à UNIVERSIDADE FEDERAL DE LAVRAS/UFLA, Caixa Postal 37 - 37200-000 - Lavras, MG, como parte das exigências para obtenção do grau de "Mestre" em Fisiologia Vegetal.

2. Professor Adjunto do Departamento de Biologia da UFLA.

3. Professora Adjunto do Departamento de Biologia da UFLA.
} 


\section{INTRODUCTION}

Areas surrounding hydroelectric reservoirs are not only subject to damage caused by the removal of the superficial soil layer but also to the effects of periodic flooding that are followed, paradoxically, by characteristic periods of water restriction in the soil.

Plant tissue responses to water stress depend on the physiological properties of the cell components and the anatomic characteristics that regulate the transmission of the water stress effect to the cells. The difference in the response to water stress among mature regions and regions of tissue growth seems to be due to anatomic differences (Matsuda \& Rayan, 1990).

Anatomical alterations may occur in plants under water deficit to protect and adapt the species to this stress. These alterations are probably due to lignin or suberin deposits found in the exodermis, endoderm and cell layers neighboring the root cortex and medulla (Baruch \& Mérida, 1995) that protect against desiccation and cortex cell death (Sharp \& Davies, 1985).

Tissues exposed to environments with low water availability have generally shown reduction in cell size, increase in vascular tissue and cell wall thickness (lignification) (Levitt, 1980; Pitman et al. 1983). Cell elongation is expected to be more sensitive than cell division (Levitt, 1980).

Baruch \& Mérida (1995) also observed in forage grasses differences in the size of the root transversal section area and the proportion of aerenchymas in plants submitted to water stress. Aerenchymas formed under these conditions may interrupt the radial movement of water in the roots thus preventing water loss from the plants to the soil (Huang \& Fry, 1998).

A decrease in the xylem vessel size close to the endoderm serves to maintain conduction but at lower rates during drought periods thus helping to re-supply larger vessels while the water supply is renewed (Millar et al. 1968; Blizzard \& Boyer, 1980).

The greatest tendencies in roots formed under excess water conditions are (a) to increase the diameter; (b) to reduce the absorption hairs; (c) to ramify and have short roots; (d) to increase the number and dimension of the intercell spaces; (e) to decrease the cell size with the increase in the suberization and lignification of the wall and (f) to reduce the root weight, which contributes to the decrease in the root/canopy ratio (Durbin, 1971).

Plants tolerant to submergence and/or flooding develop morphoanatomical structures that permit oxygen diffusion from the canopy to the root tissues, represented by the formation of aerenchyma tissues in the base part of the stem and roots and by lenticel formation in tree species (Kawase, 1981; Laan \& Blom, 1990). These structural modifications in the tissues of the base region of the stem and roots are associated with an increase in ethylene concentration in the tissues and in the cellulase activity, causing loosening in the cell walls and a consequent distribution of the root cortex tissues forming intercell spaces or aerenchymas that increase the atmospheric $\mathrm{O}_{2}$ diffusion maintaining aerobic respiration and water and nutrient absorption (Kawase, 1981; Perata \& Alpi, 1993; He et al. 1994).

The objective of this study was to assess the root anatomical characteristics of three grasses (Echinochloa pyramidalis (Lam.) Hitche. \& Chase, Setaria anceps Stapf ex Massey and Paspalum paniculatum L.) that are promising for re-vegetating areas surrounding hydroelectric reservoirs submitted to different water regimens.

\section{MATERIAL AND METHODS}

The plants used in this study were produced by asexual propagates (cuttings) that were removed from plants in the experimental field of the Biology Department/UFLA.

In July 1998 the propagates were planted in pots containing $5 \mathrm{~kg}$ substrate consisting of soil, sand and organic material (cattle manure) at a ratio of 2:1:1 and $12.5 \mathrm{~g} / \mathrm{pot}$ of simple superphosphate were added. The plants were water daily until the start of the treatments maintaining the soil close to field capacity.

The experiment consisted of six treatments. For each species (canaran, setária and paspalo) two sets of eight pots were selected with four shoots/pot. One set of pots was watered daily throughout the experimental period (irrigated treatment) while the other sets were not watered (non- irrigated treatment), marking the start of the experiment, that ended 12 days after the watering was stopped when the plants presented acute symptoms of wilting and curling. After this period, six pots of each species were taken to concrete tanks $(300 \mathrm{~cm} \times 100$ $\mathrm{cm} \times 60 \mathrm{~cm}$ ) used in flooding studies, where the root system remained submerged for 30 days (RS Submergence)

After the end of the low water availability experiment and the 30-day submerged root system experiment, samples were taken from the mid portion of several roots and fixed in FAA (formaldehyde + acetic acid $+70 \%$ ethylic alcohol) for 72 hours and kept in $70 \%$ alcohol until cutting.

The cuts were hand made using a razor blade and material inclusion in stalk were later lightened in sodium hypochloride solution at $20 \%$ commercial product

Ciênc. agrotec., Lavras. V.27, n.2, p.393-397, mar./abr., 2003 
for a period of three to five minutes and then washed three times in distilled water. The material was then neutralized with acetic acid solution at $5 \%$ for one minute and the washings were repeated. The samples were stained by immersion in iodine acetic green stain for two to three minutes, followed by three washes in distilled water and immersion in Congo red stain for three to five minutes and the washes were repeated (Dop \& Gautié, 1907). Semi-permanent slides were mounted later with glycerinated water and luted with enamel. The slides were then observed under a microscope and microphotographed.

\section{RESULTS AND DISCUSSION}

Covering tissue was observed in the transversal root section of the canarana, sestária and paspalo species (Figure 1) formed by the unistratified epiderm and anatomic differences among the treatments for the external cortex.

In canerana (Figure $1 \mathrm{a}, \mathrm{b}, \mathrm{c}$ ) the external cortex with three layers of heterodiameteric cells covered by a fairly thick cell wall of lignin and/or suberin in the nonirrigated treatment was observed below the unistratified epiderm (a); one layer below the epiderm without thickening and two layers with thickening of lignin and/or suberin in the irrigated treatment (b). a layer below the epiderm without thickening was observed in the root system submersion treatment (c) and only one cell layer with lignin and/or suberin thickening.

In Setária (Figure 1. d, e, f) a unistratified epiderm and the external cortex with two layers of heterodiameteric cells were observed in the non-irrigated treatment (d); two to three layers of heterodiametric cells were observed in the irrigated treatment (e) and one to two layer of heterodiametric cells in the treatment with submerged root system (f). The presence of cells with thickened lignin and/or suberin walls was not observed in the external cortex.

The external paspalo cortex (Figure 1. g, h, I) had two layers in the non-irrigated treatment $(\mathrm{g})$; one to two layers of cells in the irrigated treatment (h) and two to three layers of cells in the treatment with root system submersion (i) and all the cell walls were thickened with lignin and/or suberin.

This external cortex that has a lignin and/or suberin lamella covered by a thick cellulose wall may form a mechanical protection controlling water and solute flow in the roots. This compact external cortex may also have the function of protecting the cortex cells from collapse due to the hydrostatic pressure in the submerged roots and may also protect against desiccation and death of the root cortex cells exposed to water shortage. These aspects are mentioned as a characteristic of the exoderm by Seago \& Marsh (1989) and Sharp \& Davis (1985);

Canarana and paspalo are species adapted to flooded environments and therefore presented the external cortex with a thick cell layer in the three treatments showing that this thickening is part of survival strategies under adverse conditions of water offer.

An increase in the percentage of aerenchyma area was observed in all the species in the submerged root system treatment compared to the irrigated treatment (Control).

The presence of aerenchymas in the three species in all the treatments shows that the aerenchymas in these species seem to be constitutive, helping the plants under conditions of excess water in the soils to maintain aerobic respiration by maintaining $\mathrm{O}_{2}$ diffusion (Kawawse, 1981). According to Huang \& Fry (1998) there is a collapse of the cortex cells that gives rise to the aerenchymas, that in soils with severe water shortage may help to prevent water loss from the plants.

Baruch \& Mérida (1995) observed alterations caused by flooding mainly in regard to the proportion of aerenchymas. Under controlled conditions, the Brachaiaria mutica (Forsk.) Stapf and Echinochloa polystachya (H.B.K.) Hitch. grasses already presented much of their root system area destined for aerenchymas. Menezes Neto et al. (1995) also observed the formation of aerenchymas in açaí plantlets even under normal aeration conditions, leading to the conclusion that the aerenchymas are constitutive in this species and provide a high degree of tolerance to low oxygen availability in the soil.

There were differences in thickening in the endoderm of the species among the treatments, being uniseried with fairly thick walls (Caspary bands). It was observed that the endoderm cell wall under submerged root system conditions was $\mathrm{V}$-shaped with a greater lignin and/or suberin thickening compared to the irrigated and non-irrigated treatments.

Some alterations were observed in the medulla. The parenchyma was more sclerotized in the submerged root system treatments. This alteration was common to the three species. 


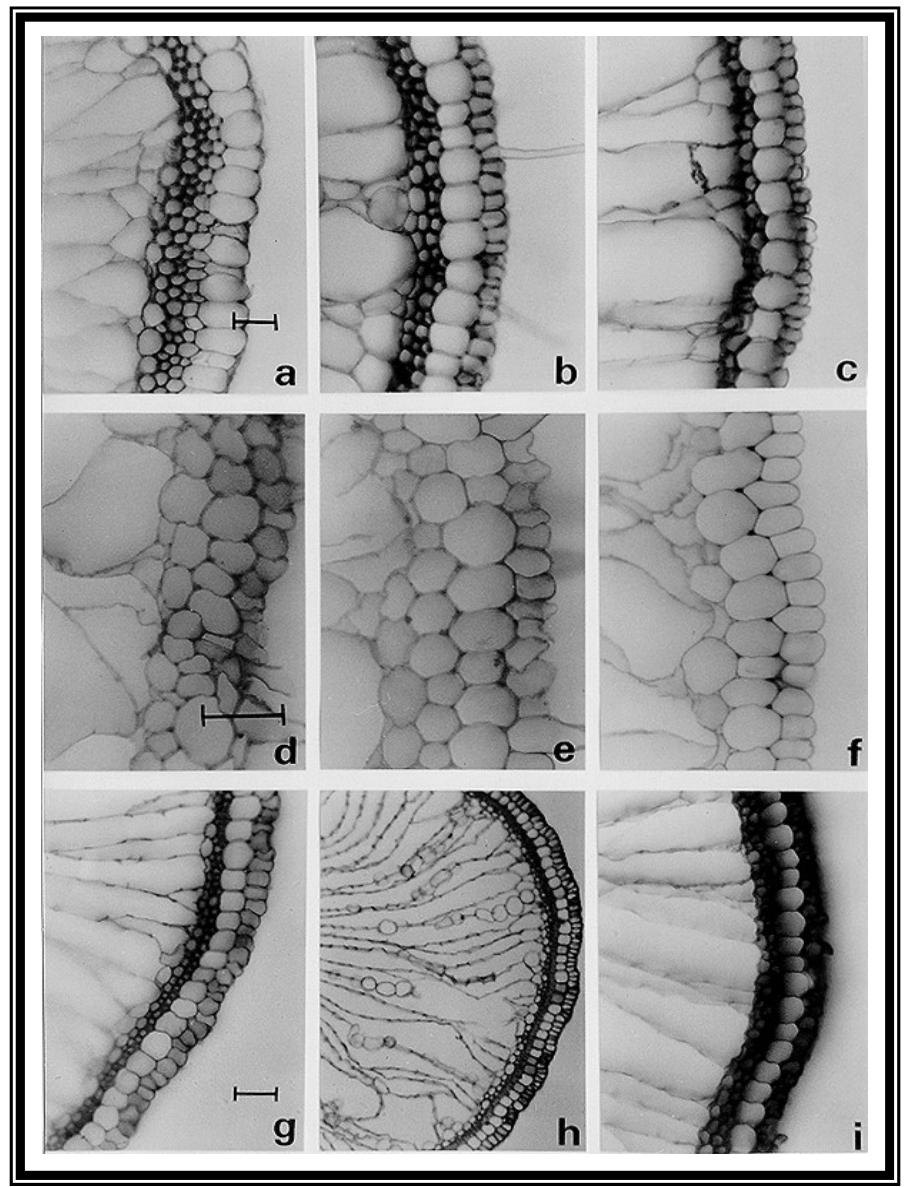

FIGURE 1 - Microphotographs with details of the root cross section showing the epiderm and external cortex of canarana $(\mathrm{a}, \mathrm{b} \mathrm{c})$ setária $(\mathrm{d}, \mathrm{e}, \mathrm{f})$ and paspalo $(\mathrm{g}, \mathrm{h}, \mathrm{i})$ in the non-irrigated, irrigated and submerged root system treatments, respectively. Ep. = epiderm, Ce. = external cortex. Bars $-50 \mu \mathrm{m}$. UFLA, Lavras-MG 1999.

Baruch \& Mérida (1995) studied the anatomy of four grasses under drought and flood conditions and obtained similar results for cell wall thickening in the endoderm, epiderm, cortex and medulla cells. Sharp \& Davies (1985) and Stasovski \& Peterson (1991) also observed suberization of the endoderm and exodermis of maize roots exposed to low water availability.

\section{CONCLUSIONS}

The anatomical assessment of plants under conditions of low water availability in the soil and root system submersion, showed that the plants responded to the treatments, presenting thickening in the external cortex cells, endoderm and medulla in both the treatments and there was greater proportion of aerenchymas in the roots of plants with submerged root system.
These observations that show adaptations to different levels for survival under adverse water offer conditions contributed to understanding their establishment in areas surrounding hydroelectric reservoirs that are subject to periods of depletion and successive flooding. However, it is pointed out that complementary studies under field conditions that assess the establishment of these species, associated to seasonal variations in the environment such as water and nutrient availability in the soil, solar radiation and air temperature, are essential to approach the question of re-vegetation of modified areas.

\section{REFERENCES}

BARUCH, Z.; MÉRIDA, T. Effects of drought and flooding on root anatomy in four tropical forage 
grasses. International Journal of Plant Sciences, Chicago, v. 156, n. 4, p. 514-521, 1995.

BLIZZARD, W. F.; BOYER, J. S. Comparative resistance of the soil and plant to water transport. Plant Physiology, Washington, v. 66, p. 809-814, 1980.

DOP, P.; GAUTIÉ, A. Manuel de techinique: botanique. Paris: J. Lamane, 1907. 534 p.

DURBIN, R. D. Abiotic diseases induced by unfavorable water relations. In: KOZLOWSKI, T. T. Water deficits and plant growth. Water and plant disease. New York: Academic Press, 1971. v. 5, 101 p.

HE, C. J.; DREW, M. C.; MORGAN, P. W. Induction of enzymes associated with lysigenous aerenchyma formation in roots of Zea mays during hypoxia or nitrogen starvation. Plant Plysiology, Washington, v. 105, n. 3, p. 861-865, 1994.

HUANG, B.; FRY, J. D. Root anatomical, physiological, and morphological responses to drought stress for tall fescue cultivars. Crop Science, Madison, v. 38, p. 1017-1022, 1998.

KAWASE, M. Anatomical and morphological adaptation of plants to waterlogging. HortScience, Virginia, v. 16, p. 30-34, 1981.

LAAN, P.; BLOM, C. W. P. M. Growth and survival response of Rumex species to flooded and submergeded conditions: the importance of shoot elongation, underwater photosynthesis and reserve carbohydrates. Journal of Experimental Botany, London, v. 41, n. 228, p. 775-783, 1990.

LEVITT, J. Responses of plants to environmental stress: volume II. Water, radiation, salt, and other stress. New York: Academic Press, 1980. 339 p.
MATSUDA, K.; RAYAN, A. Anatomy: a key factor regulating plant tissue response to water stress. In: KAFTERMAN, F. Environmental injury to plants. San Diego: Academic Press, 1990. 290 p.

MENEZES NETO, M. A.; ALVES, J. D.; OLIVEIRA, L. E. M. Anaerobic metabolism of Euterpe oleraceae. II- Plant tolerance mechanism to anoxia. Revista Brasileira de Fisiologia Vegetal, Londrina, v. 7, n. 1, p. 47-51, 1995.

MILLAR, A. A.; DUYSEN, M. E.; WILKINSON, G. E. Internal water balance of barley under soil moisture stress. Plant Physiology, Washington, v. 43, p. 968972, 1968.

PERATA, P.; ALPI, A. Plant responses to anaerobioses. Plant Science, Limerick, v. 93, n. 1-2, p. 1-17, 1993.

PITMAN, W. D.; HOLT, E. C.; CONRAD, B. E.; BASHAW, E. C. Histological differences in moisturestressed and nonstressed kleingrass forage. Crop Science, Madison, v. 23, p. 793-795, 1983.

SEAGO JUNIOR, J. L.; MARSH, L. C. Adventitious root development in Thypha glauca, with emphasis on the cortex. American Journal of Botany, Columbus, v. 76, p. 909-923, 1989.

SHARP, R. E.; DAVIES, W. J. Root growth and water uptake by maize plants in drying soil. Journal of Experimental Botany, Oxford, v. 36, p. 1441-1456, 1985.

STASOVSKI, E.; PETERSON, C. A. The effects of drought and subsequent rehydration on the structure and vitality of Zea mays seedling roots. Canadian Journal of Botany, Ottawa, v. 69, p. 1170-1178, 1991. 